\title{
The Coup d'Oeil: On a Mode of Understanding
}

\author{
Lorraine Daston
}

\section{The Overview and the Algorithm}

In The Nature of Rationality (1993), Robert Nozick imagined himself and his colleagues being put out of business by AI algorithms that would, on the basis of weighted feedback from the environment, evolve rules for when to accept beliefs as genuinely rational:

In the study of reliable processes for arriving at belief, philosophers will become technologically obsolescent. They will be replaced by cognitive and computer scientists, workers in artificial intelligence, and others. Our understanding thereby will progress, but the nature of this understanding will change: computer simulations will replace (a theory presenting) structurally revealing rules with a face validity that people can appreciate and apply. This will be useful to us-machines will be produced to do intricate tasks-but it will not be what philosophers earlier had hoped for: rules and procedures that we ourselves could apply to better our own beliefs, surveyable rules and procedures-I take the term from Ludwig Wittgenstein — that we can take in and understand as a whole and that give us a structurally revealing description of the nature of rationality. ${ }^{1}$

Nozick's use of "surveyable" to mean what human beings "can take in and understand as a whole" may be controversial as an interpretation of

1. Robert Nozick, The Nature of Rationality (Princeton, N.J., 1993), p. 76. 
what Ludwig Wittgenstein meant by the German word übersichtlich. ${ }^{2}$ But it does capture the essentials of a form of understanding that has been associated with mathematical proof (the primary context in which Wittgenstein used the term) since at least the seventeenth century, angelic cognition (the Latin intuitio) since the thirteenth century, and with an indispensable military skill of officers and generals (the French and later also English and German coup d'oeil) since the eighteenth century. ${ }^{3}$ The characteristics of this form of understanding are that it is: (1) holistic, taking in a complex object in all of its detail as a whole; (2) sudden or instantaneous, occurring all at once rather than as the conclusion of a chain of reasoning; (3) structural, revealing the essential aspects of the object and the interconnections of its parts; (4) visual, either literally or metaphorically; and (5) at once inscrutable and irrefragable, resisting both analysis and doubt. Depending on context, this form of understanding has been variously opposed to the piecemeal, the procedural, the painstaking, and the pedantic but also to logical rigor, attention to detail, narrow focus, mechanical rule following, and step-by-step demonstration.

In what follows, I will argue for the distinctiveness of this form of understanding, which I will for the sake of convenience call the coup d'oeil because its elements and practices crystallized under that name circa 17501850 , in association with the new profession of military engineer geographers. There are anticipations of at least some aspects of this species of understanding in earlier periods (for example, in thirteenth-century angelology), and there are also other associated practices in the late eighteenth and early nineteenth centuries (for example, the invention of the panorama and the rise of Humboldtian science). ${ }^{4}$ In the late nineteenth and early

2. For a discussion of the relative merits of these translations and the issues of interpretation that hinge on them, see Stefan Majetschak, "Survey and Surveyability: Remarks on Two Central Notions in Wittgenstein's Later Philosophy," Wittgenstein-Studien 7 (Feb. 2016): 65-80. Wittgenstein's English translators have variously rendered übersichtlich as "perspicuous," "synoptic," "capable of being taken in," "commanding a clear view," and "surveyable" (p. 65).

3. See especially Ludwig Wittgenstein, Bemerkungen über die Grundlagen der Mathematik [1956], ed. G. E. M. Anscombe, Rush Rhees, and G. H. von Wright, vol. 6 of Werkausgabe (Frankfurt am Main, 1984), pp. 143-51, 158-75. On Wittgenstein's use of übersichtlich and its cognates in other works, see Majetschak, "Survey and Surveyability."

4. On Humboldtian science, named for the Prussian naturalist Alexander von Humboldt (1769-1859), see Michael Dettelbach, "Humboldtian Science," in Cultures of Natural History, ed. N. Jardine, J. A. Secord, and E. C. Spary (New York, 2000), pp. 287-304.

Lorraine Daston is director at the Max Planck Institute for the History of Science, Berlin, permanent fellow of the Wissenschaftskolleg zu Berlin, and visiting professor in the Committee on Social Thought at the University of Chicago. Her most recent book is Against Nature (2019). 
twentieth centuries, the coup d'oeil as a form of understanding, once strongly linked to mathematical rigor in proofs and mathematical exactitude in techniques such as land surveying, came to be opposed to these values, not only in debates over the foundations of mathematics, but also at the more mundane level of new practices of heavy-duty calculation that spread with the use of the first reliable calculating machines after circa 1900. It is these latter practices that converted algorithms from the most transparent to the most opaque operations in mathematics and made Nozick's opposition of AIgenerated rules to surveyability thinkable.

What I will not attempt is to bring this historical sketch (for it is no more than that) to bear on Wittgenstein's use of the term übersichtlich. It would be presumptuous for a rank amateur to offer an opinion concerning a matter upon which learned specialists disagree. ${ }^{5}$ Should Wittgenstein scholars find something illuminating in the following, so much the better. But it was not written with them in mind. My quarry is instead the specific form of understanding that Nozick picked out-rightly or wrongly — with the Wittgensteinian term surveyable and its history.

\section{How Angels Think}

Creation is still young, and Adam and Eve in Eden receive a visit from the angel Raphael. While Eve is sent to gather "each plant and juiciest gourd" for the ur-dinner party, Adam interrogates their guest about the differences between humans and angels (fig. 1). Raphael's reply progresses seamlessly from digestive systems to intellects:
Man's nourishment, by gradual scale sublimed,
To vital spirits aspire, to animal,
To intellectual; give both life and sense,
Fancy and understanding; whence the soul
Reason receives, and Reason is her being,
Discursive, or intuitive: discourse
Is oftest yours, the latter most is ours,
Differing but in degree, of kind the same. ${ }^{6}$

John Milton has packed a great deal of scholastic theology into this passage from Paradise Lost, although his emphasis upon the continuity

5. On these disagreements, see Majetschak, "Survey and Surveyability"; Mathieu Marion, "Wittgenstein on Surveyability of Proofs," in The Oxford Handbook of Wittgenstein, ed. Oskari Kuusela and Marie McGinn (New York, 2011), pp. 138-61; and Felix Mühlhölzer, "A Mathematical Proof Must Be Surveyable': What Wittgenstein Meant by This and What It Implies," Grazer Philosophische Studien 71, no. 1 (2006): 57-86.

6. John Milton, Paradise Lost, ed. John Leonard (New York, 2003), pp. 110, 114. 


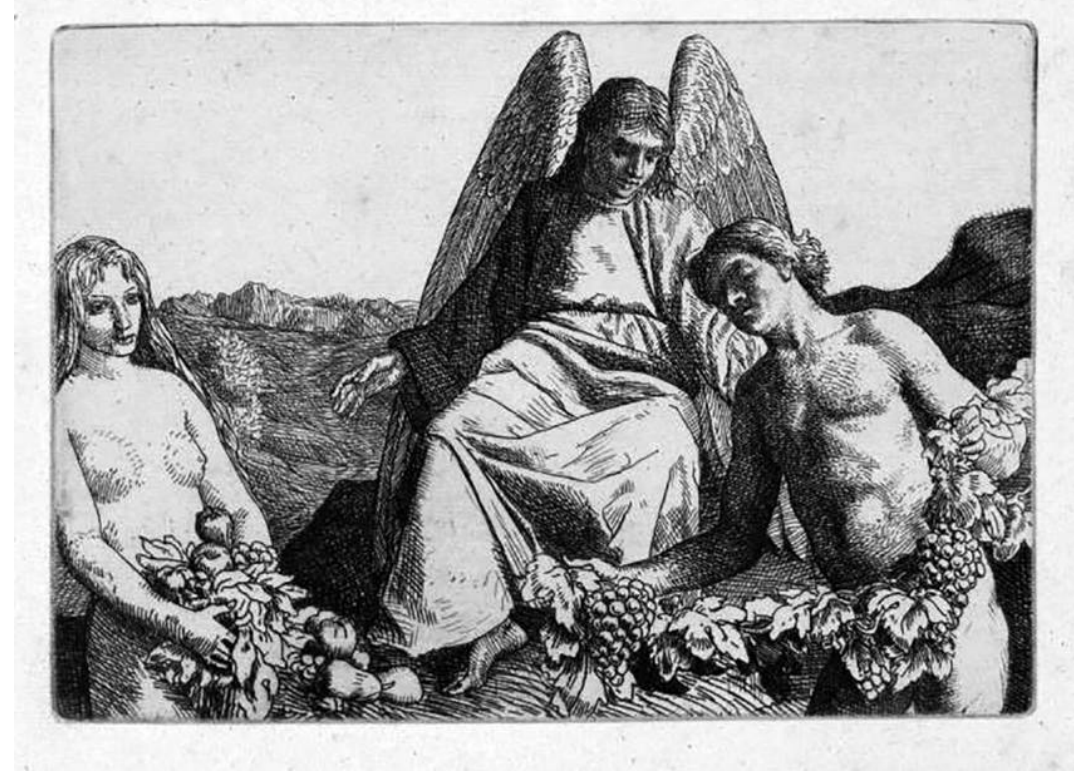

FIGURE 1. William Strang, “Adam and Eve Entertain Raphael,” in Paradise Lost by John Milton: A Series of Twelve Illustrations (1896).

of human and angelic intellects (and digestions) was controversial. ${ }^{7}$ For our purposes, it is Raphael's distinction between human discursive reasoning and angelic intuition that is of interest. Milton's "discursive" stems from the Latin discursivus, pertaining to reasoned argument, including both logical deduction and mathematical demonstration; "intuitive" (or intuition) derives from intueri, meaning to look or contemplate, which in this context refers to immediate knowledge obtained without further ratiocination. For scholastic philosophers such as Thomas Aquinas, angelic intuition understood immediately and thoroughly what was truly intelligible about any object of knowledge, namely its universal form. In contrast to the human intellect, which must first by analysis (resolutio) abstract the intelligible form from the matter that acts upon the senses, the angelic intellect has no sense organs and apprehends the form directly by synthesis (compositio), independently of space and time. Although only the divine mind can understand all things simultaneously, angelic intellects are superior to

7. The key point, disputed by Bonaventure and Thomas Aquinas in the thirteenth century, was whether angels were intelligences united with bodies (Bonaventure) or whether they were pure spirits subsisting without matter (Aquinas). Milton evidently sided with Bonaventure in endowing angels with digestive tracts and a hearty appetite. 
those of humans because of their immediate and infallible grasp of form. ${ }^{8}$ Milton's opposition of discursive and intuitive reasoning echoes Aquinas's contrast between human analysis and angelic synthesis, albeit in a more egalitarian formulation than that which Aquinas, who had firmly asserted the superiority of angelic intellects, would have countenanced.

Despite the fact that some of these doctrines were condemned by the Bishop of Paris in 1277, scholastic angelology proved remarkably durable, as Milton's formulation testifies. ${ }^{9}$ There are also arguably less explicit traces of the doctrine of angelic intuition in nontheological seventeenth-century sources, notably in texts relating to the mathematical sciences. One such candidate might be René Descartes's Rules for the Direction of the Mind (circa 1628), in which he rehearsed the familiar distinction between intuition and deduction "on the grounds that we are aware of a movement or a sort of sequence in the latter but not in the former, and also because immediate self-evidence is not required for deduction, as it is for intuition; deduction in a sense gets its certainty from memory.” Two features distinguished intuition: clarity and distinctness, and simultaneous and nonsuccessive grasp of the whole. Descartes also firmly distinguished between intuition and "the fluctuating testimony of the senses or the deceptive judgment of the imagination": despite the Latin etymology that linked intuition with vision, Descartes's version had as little to do with the senses as Aquinas's had. ${ }^{10}$

However, unlike the scholastic angelologists (but like Milton), Descartes seemed to believe that with practice, step-by-step deduction might be accelerated to the point that it blurred into a single intuition: "If after intuiting a number of simple propositions, we deduce something else from them, it is useful to run through them in a continuous and completely uninterrupted train of thought, to reflect on their relations to one another, and to form a distinct and, as far as possible, simultaneous conception of several of them." Intuitions must not only be clear and distinct, Descartes explains; they "must be understood all at once, and not bit by bit."

Following Pierre Hadot and Arnold I. Davidson, Matthew L. Jones described this Cartesian attempt to merge deduction and intuition as a spiritual exercise, akin to those practiced by the ancient Stoics or, in

8. See Thomas Aquinas, Summa contra gentiles, 2.91-101.

9. See David Keck, Angels and Angelology in the Middle Ages (New York, 1998), p. 112.

10. René Descartes, Rules for the Direction of the Mind, trans. Dugald Murdoch, in The Philosophical Writings of Descartes, trans. John Cottingham, Robert Stoothoff, and Murdoch, 2 vols. (New York, 1985), 1:15, 14.

11. Ibid., p. 37. 
Descartes's own time, by Ignatius Loyola and the Jesuit order. ${ }^{12}$ It is certainly a striking example of the ambition to perfect the plodding discursive intellect into an intuitive one capable of grasping demonstrations as wholes - and thereby effectively to vindicate Milton's claim that human and angelic intellects differed "but in degree, of kind the same."

Descartes makes no mention of angels in the Rules. But the hylomorphic scholastic language of form and matter that framed the contrast of angelic and human cognition also figured prominently in early seventeenthcentury accounts of mixed mathematics, the mathematical study of objects that mingled form and matter, including astronomy, optics, music, and rational mechanics. Descartes's friend and longtime correspondent on scientific matters, the Minim friar Marin Mersenne, classified the various branches of mixed mathematics according to the proportions of form to matter each contained: the greater the predominance of form, the more certain the science. At the high end (all form—no matter) were the "pure" mathematical disciplines, geometry and arithmetic, descending by degrees through optics, music, and other disciplines admixed with "physics." Mersenne did not doubt that physics was governed by principles as "certain and evident" as those of arithmetic but believed that our understanding of them was clouded by the vicissitudes of matter (for example, the movements of air in the case of music) and the unreliable operation of the senses. Pure form-now identified exclusively with mathematics — was still the only guarantee of certain knowledge. ${ }^{13}$

Angelic intuition displays some but not all features of coup d'oeil understanding: it is immediate, holistic, indubitable, and perhaps (at least in Descartes's mathematical version) also structural, a faculty that discerns interconnections. But it is pointedly detached from the senses, including vision. At most intuition operates via the eye of the mind, not that of the body. It is all coup, and no oeil.

\section{The Commanding View}

The term coup d'oeil (glance) was in widespread use in French by the late seventeenth century and belongs to a flock of similar constructions based on the word coup (blow, attack), all denoting suddenness and force

12. See Matthew L. Jones, "Descartes's Geometry as Spiritual Exercise," Critical Inquiry 28 (Autumn 2001): 40-71; Pierre Hadot, La Philosophie comme manière de vivre (Paris, 2001); and Arnold I. Davidson, "Introduction: Pierre Hadot and the Spiritual Phenomenon of Ancient Philosophy," in Hadot, Philosophy as a Way of Life: Spiritual Exercises from Socrates to Foucault, trans. Michael Chase, ed. Davidson (Malden, Mass., 1995), pp. 1-45.

13. See Marin Mersenne, Les Questions theologiques, physiques, morales et mathematiques, in Questions inouyes (1634; Paris, 1985), pp. 357-59. 


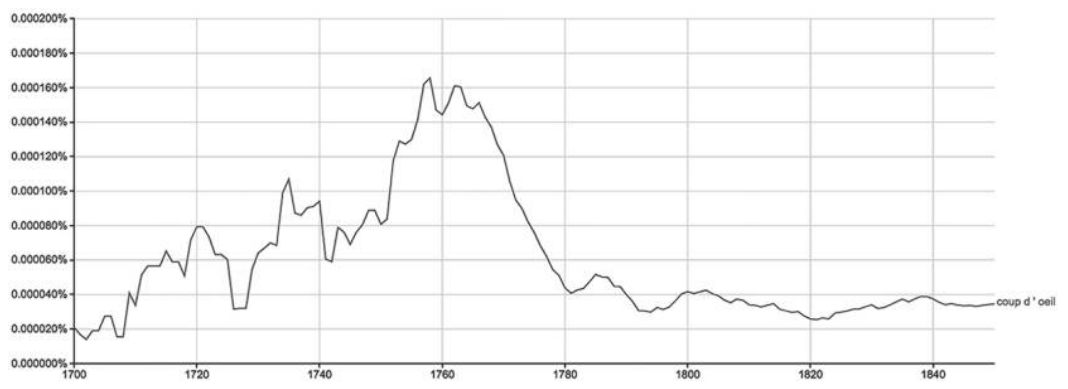

FIGURE 2. Google Ngram, “coup d'oeil” in French books, 1700-1850.

(coup de foudre, coup d'état). ${ }^{14}$ A Google NGram of the frequency with which the phrase appears in the Google Books sample shows a steep, high peak between roughly $1740-1780$, which is when the term becomes synonymous with a brief, synoptic view of some topic (often a region or country) (fig. 2). ${ }^{15}$ It is also when the term takes off as a much-vaunted and carefully cultivated qualification for commanding army officers. A key source seems to have been a compilation of the papers of the French officer Jean-Charles Folard, overseen and published in 1761 with a preface by none other than Frederick II of Prussia (who claimed to have retrieved the "diamonds from the dung-heap" of Folard's copious military writings). ${ }^{16}$ The term occupies pride of place as the subject of the first chapter, where it is enshrined as the ability without which no commander can "hope for victory." Folard did not invent the military term of art coup d'oeil, but he elevated it to a position of primary importance and insisted that it could be, indeed must be, learned. "The military coup d'oeil is nothing other than the art of knowing the nature and different sites [situations] of the country in which one is at war or wants to prosecute a war, the advantages and disadvantages of the camps and posts one wants to occupy, as well as those that could be favorable or unfavorable to the enemy" (EF, pp. 5, 4).

Folard's coup-d'oeil was doubly visual. First, it could be acquired only by the firsthand exploration of every brook, hedge, hill, valley, and hamlet of the army's territory, all of which the general must "see with his [own] eyes, and never those of another." Second, it fostered the imagina-

14. See Dictionnaire historique de la langue française, 3 vols. (Paris, 1998), s.v. "coup," 1:918-21 and "oeil," 2:2436-38.

15. See for example Joseph de La Porte, Almanach chinois, ou Coup d'oeil curieux sur la réligion, les sciences, les arts (Peking, 1761).

16. [Frederick II of Prussia], prologue to L'Esprit du chevalier Folard, tiré de ses commentaires sur l'histoire de Polybe, pour l'usage d'un officier, de main de maître (Leipzig, 1761), p. iii; hereafter abbreviated $E F$. 
tive projection of future possibilities of attack and defense. While observing whether "the church is good, whether the village might be commanded from a height, whether it can be gotten around," the officer "will attack [the village] in the imagination, he will defend it in the same way: nothing seems to me more capable of forming the coup d'oeil and judgment than this method" (EF, pp. 15, 20).

What Folard's coup d'oeil is not is instantaneous, holistic, structural, or indubitable; it partakes of almost none of the qualities that distinguished the faculty of intuition. On the contrary, it is methodical, detail obsessed, and time consuming: when not waging war, the officer should practice the discipline of the coup d'oeil by hunting or traveling on foot; meticulous note-taking for consultation at leisure is a necessary supplement to field observation. Nor is there any trace of the overview that takes in a whole scene at a glance. Folard's commander does not survey from on high; he paces the ground, ideally retracing his steps first on foot, then on horseback, to make sure he is acquainted up close with every ditch and patch of mud that might prove a help or hindrance on the battlefield. Tellingly, only in a schematic illustration of a battlefield configuration is there anything approximating a sweeping view from above the fray (fig. 3 ).

Yet by the early nineteenth century, the military coup d'oeil had become an effortless instinct, an all-encompassing view, a swift and nearly infallible judgment akin to the taste of the artist and just as inscrutable to

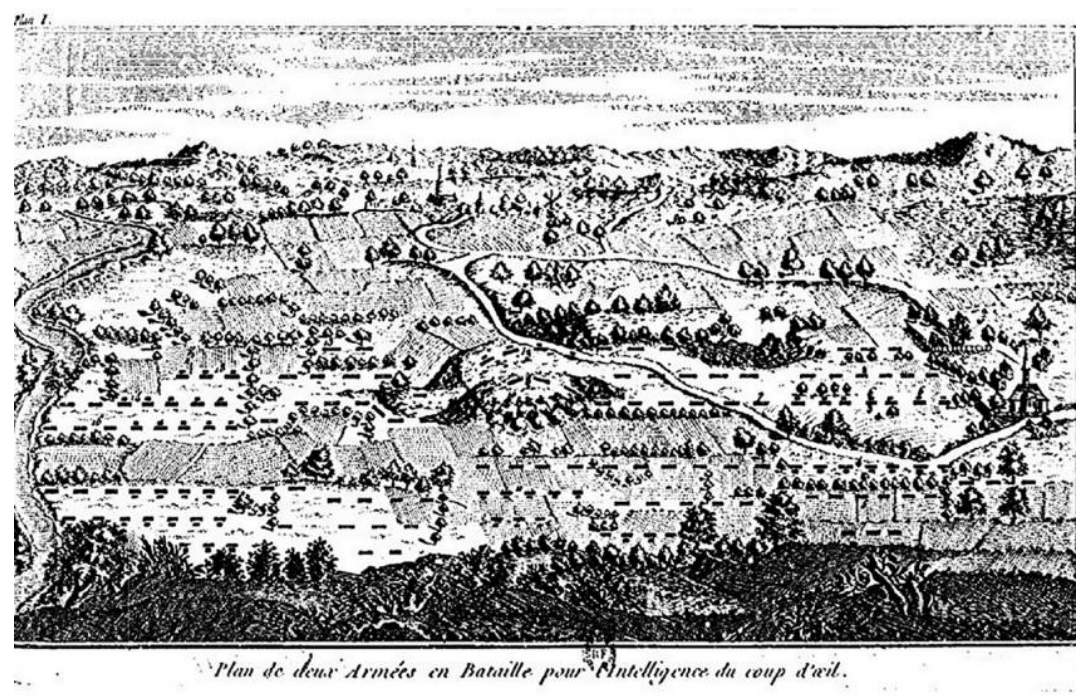

FIGURE 3. "Map of Two Battling Armies for the Intelligence of the Coup d'Oeil," in [Frederick II], L'Esprit du chevalier Folard, p. 31. 
analysis. An 1829 treatise by the French military engineer Pierre Alexandre Allent enshrined the officer's coup d'oeil as his most important asset: "to see in a coup d'oeil what can be done: to embrace the whole, seize the essential, not pausing over useless details, and never acceding to an all too frequent taste for an intemperate perfection. ${ }^{{ }^{17}}$ In this formulation, the coup d'oeil was barely a split second removed from taking action, and the Prussian general Carl von Clausewitz linked the coup d'oeil to decisiveness and presence of mind, all of which equipped the commanding officer to react to the unexpected and to turn accident into opportunity through lightning understanding and iron resolve. ${ }^{18}$ Like Clausewitz, who warned that military theory could never rival the "easy overview [leichter Überblick] of the great commander,"19 Allent argued that the coup d'oeil was the product of "neither science nor study":

this practical coup d'oeil, this (so to speak) involuntary tact, that only the habit of seeing and observing imparts; it is that of the hunter in the Alps and the Pyrenees [who] wanders in the mountains and never loses his way; it is the exquisite sentiment with which the artist distinguishes the features of an antique statue from the almost identical features of the most perfect copies.

Once acquired through long practice, the military coup d'oeil, like aesthetic connoisseurship, was exercised "without effort" and "never deceives" ("ER," pp. 172, 171, 172).

It is significant that Allent was a high-ranking military engineer. The French engineering schools established in the eighteenth century were among the first European institutions to offer a technical scientific education with a strong mathematical component, and the military Ecole de Mezières (established 1748) was by the 1760 s also training cartographers and surveyors as well as experts in artillery and fortifications. ${ }^{20}$ In 1762 , a special qualification was created for "engineer geographers," who were charged with producing detailed, accurate topographical maps for the use of the French military and crown. ${ }^{21}$ These magnificent maps required knowl-

17. Pierre Alexandre Allent, "Essai sur les reconnaissances militaires," in Recueil sur les reconnaissances militaires d'apres les auteurs les plus estimés, ed. J. Corréard (Paris, 1845), p. 165; hereafter abbreviated "ER."

18. See Carl von Clausewitz, Vom Kriege (Hamburg, 2008), pp. 75-76. Clausewitz uses the French term coup d'oeil in the German text.

19. Ibid., p. 692.

20. See Ken Alder, Engineering the Revolution: Arms and Enlightenment in France, 17631815 (Chicago, 1997), pp. 57-86.

21. See [Henri Marie Auguste] Berthaut, Les Ingénieurs géographes militaires, 1624-1831, 2 vols. (Paris, 1902), 1:4-63, and Monique Pelletier, "Formation et missions de l'ingénieur 
edge of surveying, drawing, and perspective as well as field observation and mathematics (fig. 4). By bundling the skills of field reconnaissance, practical mathematics (especially surveying), and drawing, the engineer geographers pushed Folard's methodical tramp through the countryside in the direction of a swift, synoptic understanding of the military situation of the sort afforded by an accurate topographical map.

Maps had long been tools enlisted to condense and clarify complicated topographies. Already in the fourteenth century, cartographers had attempted to provide synoptic views of the spatial layout of cities (and sometimes also of their histories), as in the case of Paolino Minorita's celebrated fourteenth-century map of Rome, which promised a "quick" and "clear" view of all points of interest. ${ }^{22}$ Sixteenth- and seventeenth-century city views from a bird's-eye point of view (actually from an angle of between 30 and 60 degrees to the horizon, as seen from a tower or church steeple) created the illusion of embracing the entire city of Venice or Amsterdam in one sweeping glance, down to the details of individual landmark buildings. Historians of cartography have pointed out how these bird's-eye views shade into, on the one hand, landscapes, and, on the other, views of military fortifications. ${ }^{23}$ The impression of the coup d'oeil, of seeing everything at a glance, is in fact achieved by seamlessly integrating multiple points of view. No hilltop or church bell tower was ever high enough yet also central enough to give a single observer the entire city in all the desired detail. These bird's-eye-view city maps were usually mosaics of multiple views from different vantage points pieced together like parts of a puzzle, a process repeated by the printer who fitted together multiple woodcuts, as in the case of the gigantic Jacopo de' Barbari view of Venice (fig. 5). What the viewer sees is in fact not a bird's-eye point of view but rather more like an angel's-eye point of view, which merges all the individual perspectives into one synoptic image. Already in the seventeenth century,

géographe militaire au XVIIIe siècle," in L'Oeil du cartographe et la représentation géographique du Moyen Âge à nos jours, ed. Catherine Bousquet-Bressolier (Paris, 1995), pp. 73-92. The original large-scale maps produced by the engineer geographers in the 1760 are still preserved at the Bibliothèque National de France, Cartes et Plans, Ge FF13292.

22. Tanja Michalsky, "Grata Pictura and Mapa Duplex: Paolino Minorita's Late Medieval Map of Rome as an Epistemological Instrument of a Historiographer," Convivium 2, no. 1 (2015): 48 .

23. See Naomi Miller, Mapping the City: The Language and Culture of Cartography in the Renaissance (London, 2003), pp. 151-58, 179; Marion Hilliges, "Der Stadtgrundriss als Repräsentationsmedium in der Frühen Neuzeit," in Aufsicht-Ansicht-Einsicht: Neue Perspektiven auf die Kartographie an der Schwelle zur Frühen Neuzeit, ed. Michalsky, Felicitas Schmieder, and Gisela Engel (Berlin, 2009), p. 355; Daniela Stroffolino, "Rilevamento topografico e processi construttivi delle 'vedute a volo d'ucello," ' in L'Europa moderna: Catografia urbana e vedutismo, ed. Cesare de Seta and Daniela Stroffolino (Naples, 2001), pp. 57-67. 


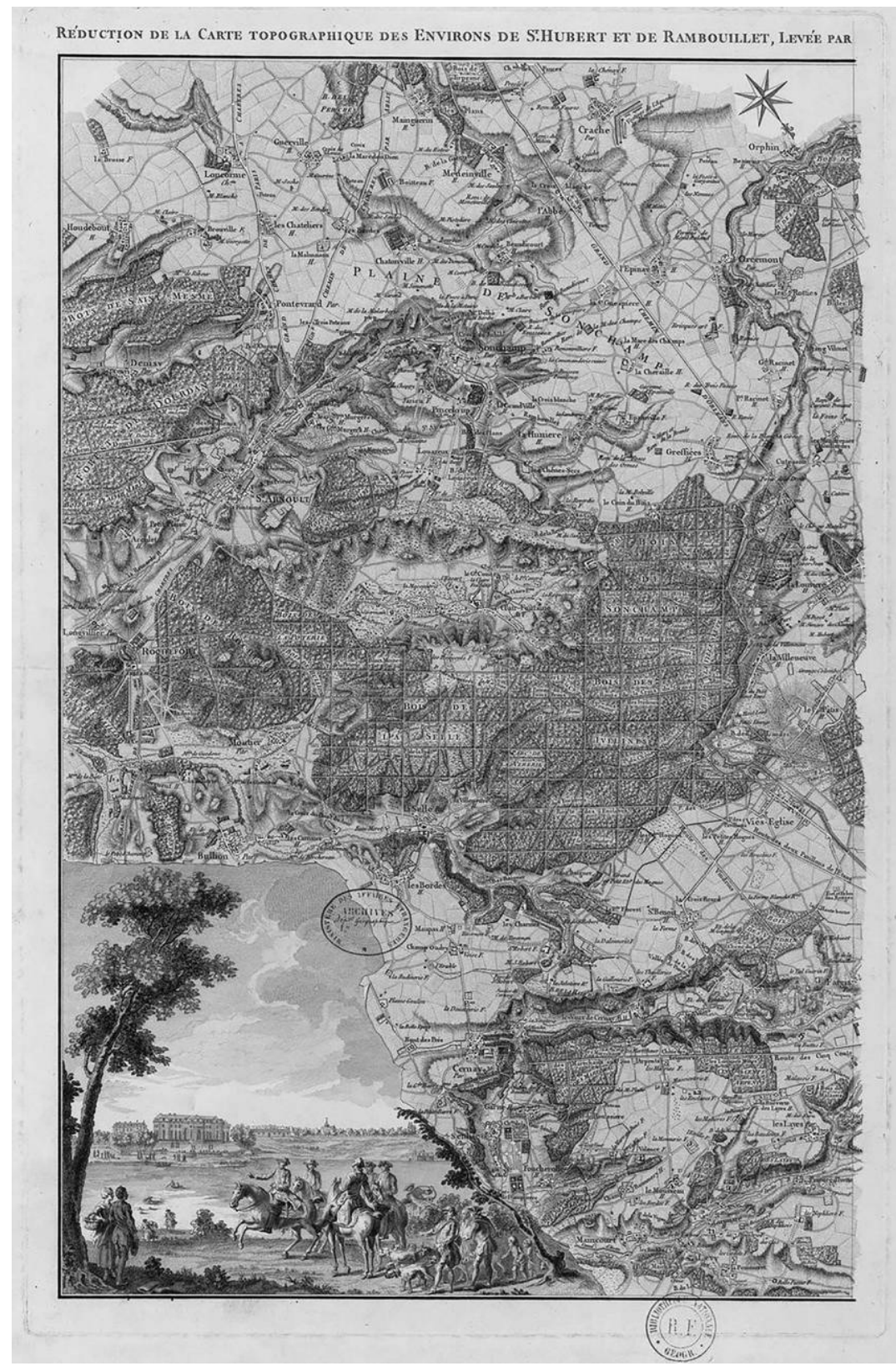

FIGURE 4. "Réduction de la carte topographique des environs de St Hubert et de Rambouillet : Levée par ordre du roi, par les ingénieurs géographes des camps et marches des armées de sa majesté / sous la direction du Sr Berthier," Bibliothèque Nationale de France, gallica.bnf.fr/ark:/12148/btvib8593349o/fi.item.r=Berthier.zoom

This content downloaded from 141.014.238.123 on April 15, 2019 01:36:59 AM All use subject to University of Chicago Press Terms and Conditions (http://www.journals.uchicago.edu/t-and-c). 


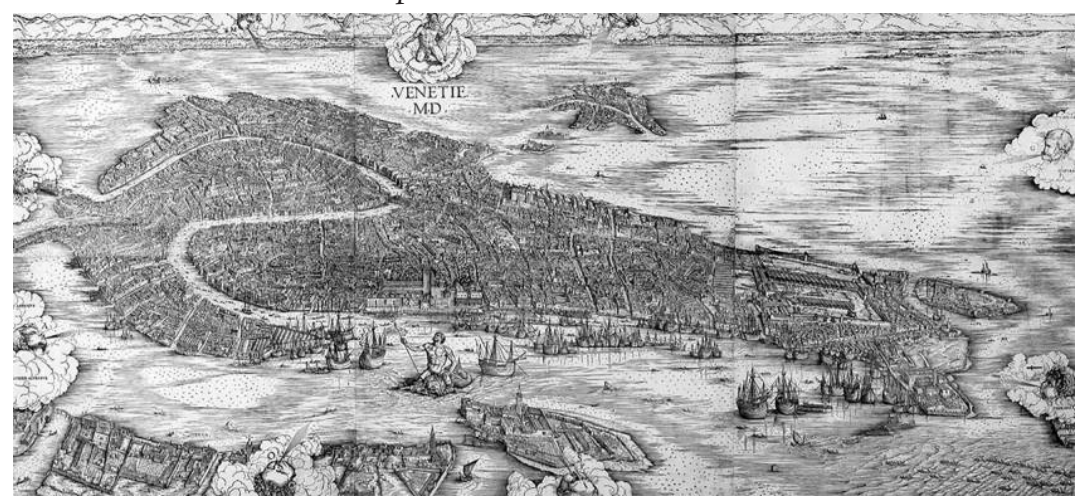

FIGURE 5. Jacopo de' Barbari, View of Venice (1500).

these impossible images carried the imprimatur of the true, a grasp of an object that was simultaneously all-embracing and minutely detailed. ${ }^{24}$ When aeronauts first ascended in Montgolfier hot-air balloons in the 1780 , they seemed to experience considerable difficulty in visually parsing a genuine bird's-eye perspective of towns and countryside viewed from above, perhaps because their expectations had been molded by such artfully and deceptively constructed city views. ${ }^{25}$

Pierre-Joseph Bourcet, who was a cartographer as well as an engineer and eventually lieutenant general under the ancien régime, marks the moment in the history of the military coup d'oeil when Folard's earthbound trek was elevated to the view from on high. Like Folard, Bourcet was a stickler for detail in reconnaissance missions and firsthand observation. Yet his own alpine experience underscored the utility of hilltop outposts that afforded an overview of broad swathes of countryside, and he warned that too much detail could obscure the view of the whole. Mathematical disciplines like the art of fortifications (highly geometricized since the sixteenth century) strengthened the coup d'oeil by developing the imagination and the ability "to grasp the advantages, the accidents of the terrain for the placement of batteries and retrenchments" (fig. 6). ${ }^{26}$ As Valeria Pansini has remarked, these aspirations were in palpable tension with one another-as indeed the synoptic sweep and minute detail of the bird's-eye city views had been as well. Bourcet's expanded vision of the coup d'oeil,

24. See Lucia Nuti, "Le langage de la peinture dans la cartographie topographique," in L'Oeil du cartographe et la représentation géographique du Moyen Âge à nos jours, pp. 53-70.

25. See Marie Thébaud-Sorger, "Les premiers ballons et la conquête du ciel: Les dimensions d'une découverte," Dix-Huitème Siècle 31 (1999): 159-77, esp. 166-70.

26. [Pierre-Joseph] Bourcet, "Mémoires attribués au général Bourcet," in Recueil sur les reconnaissances militaires d'apres les auteurs les plus estimés, pp. 5-6. 


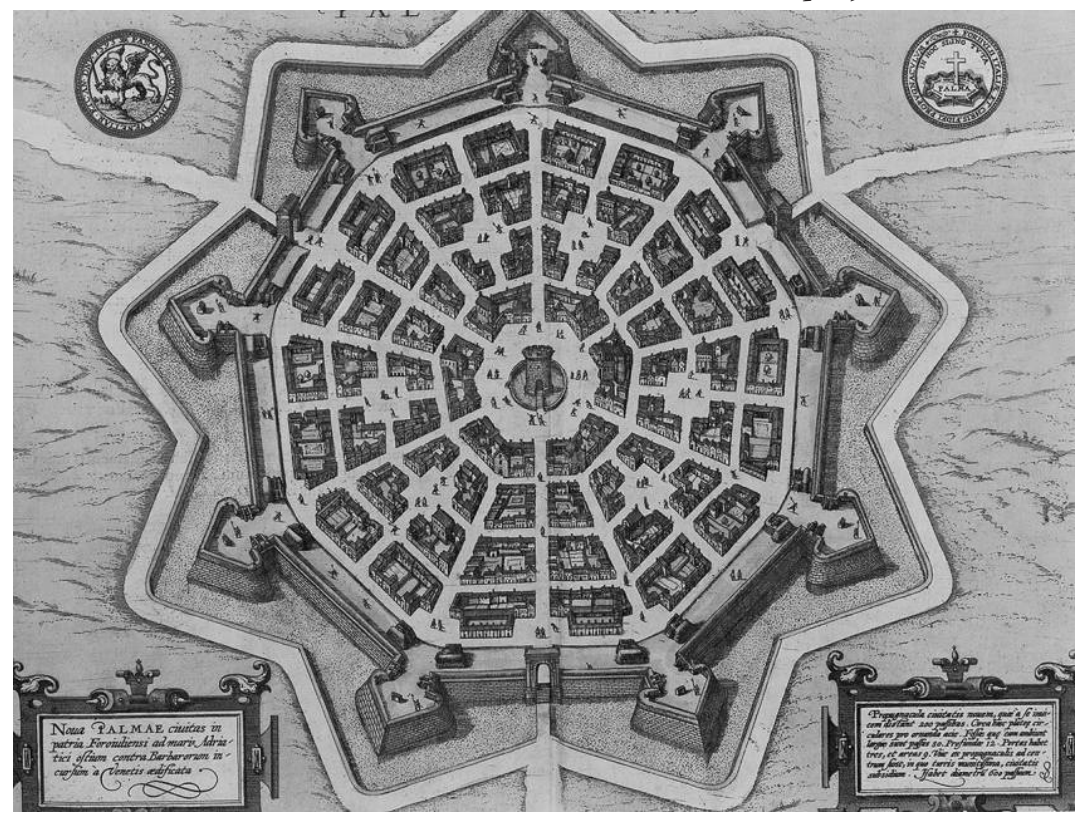

FIGURE 6. "Palmanova," plan of an ideal city, from Georg Braun and Frans Hogenberg, Civitates orbis terrarum (1598).

mirroring his own experience as cartographer and general, demanded a form of vision that was at once active and contemplative, detailed and synoptic, analytic and synthetic. ${ }^{27}$

Yet it was precisely such unattainable (one is tempted to say, angelic) epistemological ambitions that account for the glittering career of the military coup d'oeil in the late eighteenth and early nineteenth centuries. Its champions emphasized how even the most painstaking and exacting tasks, such as making the measurements necessary for surveying triangulations, could be replaced by the levé à vue (survey by eyeballing) done at top speed and without instruments. What began as a meticulous and methodical sequence of measurements, using instruments such as sextants and theodolites to survey a territory "with all the perfection that befits astronomical, geodetic, and topographic [figuré du terrein] operations," became with habit an almost unconscious set of bodily gestures that estimated distances and sized up offensive and defensive possibilities at a glance ("ER," p. 160). Often the coup d'oeil was a practical necessity. The

27. See Valeria Pansini, "L'Oeil du topographe et la science de la guerre. Travail scientifique et perception militaire (1760-1820)" ( $\mathrm{PhD}$ diss., School for Advanced Studies in Social Sciences [EHESS], 2002), pp. 298-301. 
exact mathematical methods of the surveyors were all very well in pacified territory, but under wartime conditions a rapid reconnaissance of the battlefield mayhem from a hilltop would have to suffice. At times, however, the coup d'oeil was vaunted as superior to the careful mathematical survey. Allent pointed out that some such ability was required even to draw a smooth curve among the topographer's measured points. Just as in the other arts, measurements and strict rules of proportion were for beginners, not seasoned experts, and could "not replace the coup d'oeil or taste, which alone should guide the pencil" ("ER," p. 220). In a striking reversal of the ancient hierarchy of head over hand, the savoir faire of the coup d'oeil lorded it over the mere savoir of mathematical methods.

The word intuition rarely appears in treatises on the military coup d'oeil. Instead, its champions reached for analogies with the arts, emphasizing the elements of vision, taste, and judgment. By the early nineteenth century, however, it was precisely these artistic qualities that were regularly opposed to those of meticulous, exact, methodical scientific procedure, formulated in the then-new vocabulary of "subjective" art versus "objective" science. ${ }^{28}$ There had been nothing subjective about angelic intuitions in medieval Catholic theology. On the contrary, angelic intuitions transcended the individuality of both knower and known to grasp the true essence of an object, its intelligible form. But by a kind of algebra of opposition, the fact that the coup d'oeil and intuition were by the midnineteenth century both set against explicit, step-by-step, discursive reasoning pushed them into closer semantic proximity. By associating the military coup d'oeil with artistic connoisseurship, writers like Allent celebrated the unconscious tact of the body at the expense of the conscious exactitude of the mind. In the latter part of the nineteenth century, these associations were increasingly perceived as incompatible with objectivity in science and rigor in mathematics. Once a guarantee of certainty and clarity, intuition came under suspicion as a source of error.

The military coup d'oeil nonetheless entered early nineteenth-century science by other routes. Chief among them was the panorama, a circular display of painted panels that seamlessly merged multiple central perspectives so as to give the spectator placed in the middle the illusion of being at once immersed in but also above a vast, complex scene. Patented in 1787 by the Englishman Robert Barker, the panorama (a neologism coined somewhat later from the Greek words pan and horama, meaning "all-seeing") was soon all the rage in European capitals, touted in the press and parodied

28. See Lorraine Daston and Peter Galison, Objectivity (New York, 2007), pp. 246-51. 
by Honoré de Balzac. ${ }^{29}$ Not coincidentally, the main themes of the early panoramas were cityscapes and battle scenes, the two principal loci of earlier coup d'oeil fantasies of seeing everything, all at once. Before turning to panorama painting, artist Jean-Charles Langlois had been an engineer and cartographer in the Napoleonic army, and his celebrated panoramas of the battles of Smolensk and Moskowa and other contemporary military campaigns gave thousands of spectators the sense that they had been eyewitnesses to the events depicted-despite the fact that their perspective (a composite of at least eight distinct central perspectives) could not possibly have been shared by any of the participants in the melee (fig. 7).$^{30}$

The German naturalist Alexander von Humboldt, who had viewed panoramas in Paris and Berlin, recommended the technology as a way for stay-at-home observers to cultivate an eye for what he called "landscape physiognomy," ${ }^{31}$ the characteristic blend of flora, climate, and topography that distinguished tropics from tundra, mountains from deserts. ${ }^{32}$ One could, of course, concentrate on this or that meticulously painted detail, as many viewers did, but it was also possible to spin around and take in the entire panorama in one vertiginous glance, as Humboldt himself seems to have done. ${ }^{33}$ In his early work Ansichten der Natur (Views of Nature, 1807), Humboldt had urged naturalists to "encompass nature with one glance," and espoused a research program of fertile contradictions that closely paralleled those of the military coup d'oeil: simultaneously intensely local and yet expansively global, rooted in methodical quantitative measurements and yet aspiring to a qualitative aesthetic that admired the whole of nature as an ornament (the meaning of the ancient Greek word Kosmos, which he chose as the title of his magnum opus). ${ }^{34}$

29. Stephan Oettermann, Das Panorama: Die Geschichte eines Massenmediums (Frankfurt am Main, 1980) describes the invention and diffusion of the panorama in detail, as well as possible affinities with Bentham's Panopticon, depictions of the Alps, and Montgolfier flights.

30. See François Robichon, "Langlois, magicien des panoramas," in Robichon et al., JeanCharles Langlois, 1789-1870: Le Spectacle de l'histoire (Paris, 2005), pp. 19-24.

31. Alexander von Humboldt, Ansichten der Natur, mit wissenschaftlichen Erläuterungen [1807] (1807; Frankfurt am Main, 2004), p. 245.

32. See also Humboldt, Kosmos: Entwurf einer physischen Weltbeschreibung, ed. Ottmar Ette and Oliver Lubrich (1845; Frankfurt am Main, 2004), pp. 233-34. Humboldtian science was enormously influential in the mid-nineteenth century and Humboldt himself an international celebrity. Andrea Wulf, The Invention of Nature: Alexander von Humboldt's New World (New York, 2015) describes his multifaceted career and fame.

33. See Charlotte Bigg, "The Panorama, or La Nature A Coup d'Oeil," in Observing Nature-Representing Experience: The Osmotic Dynamics of Romanticism, 1800-1850, ed. Erna Fiorentini (Berlin, 2007), pp. 73-95.

34. Humboldt, Ansichten der Nature, p. 245. See also John Tresch, The Romantic Machine: Utopian Science and Technology after Napoleon (Chicago, 2012), pp. 61-87. 


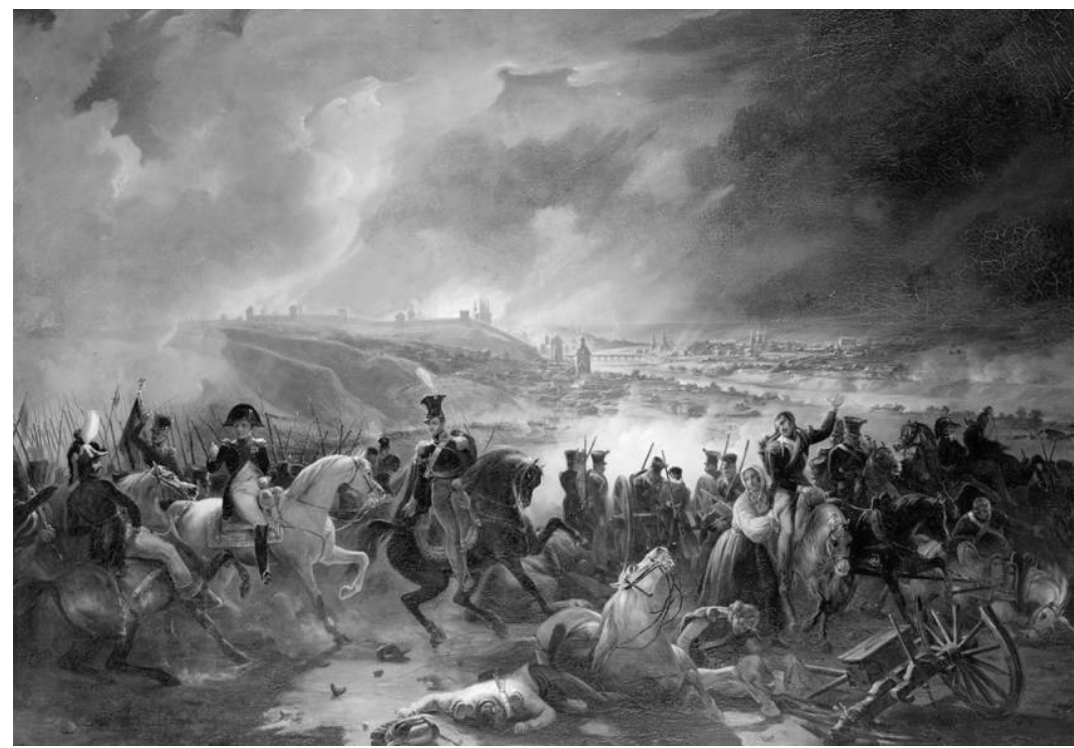

FIGURE 7. Jean-Charles Langlois, Battle of Smolensk: Night of August 17, 1812 (1839).

Coup d'oeil understanding always flirted with paradox. Like Descartes's attempts to fuse discursive reasoning and intuitive self-evidence, or the military officer's attempt to note every detail while at the same time grasping the lay of the land at a glance, Humboldt's concerted attempts to combine what he himself called subjective and objective approaches to the study of nature, quantitative and qualitative, methodical and aesthetic, painstaking and effortless, were characteristically riven. And like the bird's-eye city views and the panoramas that were its emblems, the tantalizing impossibility of the coup d'oeil was its greatest attraction. No human being can simultaneously focus on the leaves and the forest; the very word focus explains why. Human attention necessarily divides the visual field into foreground and background, crisp focus and blurry surround. As a form of vision, only the artistic tricks of composite perspectives or trompe l'oeil can conjure the illusion of parts and whole viewed all at once and all in equally sharp focus. As a form of understanding, the coup d'oeil also aspired to a way of knowing that seemed to transcend human limitations. Its objects-a mathematical proof, a battlefield, a tropical landscape-were too bounded and mundane to invoke divine omniscience. Its methods - tact and intuition born of long practice-were also too workaday to support such hubristic ambitions. Yet even if the coup d'oeil never approached anything like a God's-eye point of view, something of medieval angelology still clung to even its modern mathematical and scientific expressions. 


\section{Algorithms Transparent and Opaque}

In 1928 the mathematician G. H. Hardy delivered a lecture on mathematical proof to a Cambridge audience. Except for a brief Oxford interlude, Hardy's career had been spent almost entirely at Trinity College, Cambridge, and he once quoted with approval his Trinity College colleague John Littlewood's donnish compliment to ancient Greek mathematicians: they were "not clever schoolboys or 'scholarship candidates,' but 'Fellows of another college. "' 35 But Hardy was not an insular Oxbridge don when it came to the debates on the foundations of mathematics waged in David Hilbert's Göttingen or L. E. J. Brouwer's Amsterdam, although he referred to the entire movement to ground mathematics in logic by "the short title of 'Russell" after his erstwhile Cambridge colleague. Hardy found both the mathematical logicians (chief among them Bertrand Russell of the Principia Mathematica) and the intuitionists (whom he christened "finitists" because of their opposition to the infinitist methods of Karl Weierstrass and Georg Cantor) unappealing. However, he did accept the justice of Hilbert's distinction between two senses of mathematical proof. On the one hand, there was "the formal, mathematical, official proof, the proof inside the system"; on the other, there were the "informal, unofficial, significant proofs, in which we reflect on the meaning of every step." Yet Hardy refused to concede that "the unofficial, metamathematical, nonformal, intuitionist proof is any sense slacker or less 'rigorous' than the formal mathematical proof. The subject matter is abstract and complicated, and every step has to be scrutinised with the utmost care." 36

It is suggestive-perhaps no more than that — that Hardy compared such informal but nonetheless rigorous proofs to mapping mountain ranges, the bread and butter of military topography: "I have myself always thought of a mathematician as in the first instance an observer, a man who gazes at a distant range of mountains and notes down his observations." Like physical vision, mathematical vision came in varying degrees of acuity, and some observers could make out more mountain peaks than others. But as in the case of the military coup d'oeil, practice sharpened sight. The mathematician "sees [peak] A sharply, while of B he can obtain only transitory glimpses. At last he makes out a ridge which leads from A, and following it to its end he discovers that it culminates in B. B is now fixed in his vision, and from this point he can proceed to further discoveries." There is nothing

35. G. H. Hardy, A Mathematician's Apology (1940; New York, 1967), p. 81.

36. Hardy, "Mathematical Proof," Mind 38 (Jan. 1929): 6, 5, 16, 17; hereafter abbreviated "MP." This is the text of the Rouse Ball Lecture, which Hardy delivered at Cambridge in 1928. 
angelic about Hardy's metaphor. Nor does it simulate the suddenness of the more romantic versions of the military coup d'oeil. It is much more like Folard's methodical trudge, connecting the mountain peaks by following the ridge step-by-step in mind's eye. Some mathematical discoveries leap into view, others must be slowly pieced together. Depending on the aptitude of the pupil, a newly discovered peak is either immediately visible or discerned "through the chain of summits which led him [the mathematician] to recognise it himself. When his pupil also sees it, the research, the argument, the proof is finished" ("MP," p. 18). However befogged the initial glimpse of mountain peak B and however methodical the initial trek along the path connecting it to peak $\mathrm{A}$, once traversed, the whole chain can be taken in together; it can be seen.

Ian Hacking once contrasted two seventeenth-century ideals of mathematical proof, Cartesian and Leibnizian: "Leibniz thought that truth is constituted by proof. Descartes thought proof irrelevant to truth. . . . Leibniz's God recognizes proofs. Descartes' God is no prover. A proof might help a person see some truth, but only because people have poor intellectual vision." ${ }^{37}$ Hacking goes on to declare Hardy of the party of Descartes, on the strength of another passage from Hardy's 1928 lecture: "proofs are what Littlewood [Hardy's longtime mathematical collaborator] and I call gas, rhetorical flourishes designed to affect psychology, pictures on the board in the lecture, devices to stimulate the imagination of pupils." This does indeed sound dismissive, but read in context it is clear that Hardy thought this description of proofs was "plainly not the whole truth, but there is a good deal in it" ("MP," p. 18). The difficulty is that Hardy was neither a Cartesian nor a Leibnizian. He was both. The crisis in mathematical rigor that began with nineteenth-century doubts about the foundations of the calculus and in the early twentieth century broadened into a quest for unshakeable foundations for all of mathematics had made intuitions of the Cartesian sort an object of suspicion to most mathematicians. ${ }^{38}$ Yet Hardy refused to embrace the "Russell" view that mathematical truth was nothing more than a matter of formal relations derived one from the other in ant steps and in a rebarbative symbolism to boot. Instead, he transferred the perspicuity of Descartes's clear and

37. Ian Hacking, "Leibniz and Descartes: Proof and Eternal Truths," in Proceedings of the British Academy: Volume 59, 1973 (London, 1975), p. 179. Hacking returned to these themes in his Why Is There Philosophy of Mathematics at All? (New York, 2014), pp. 34-40, where he takes a more ecumenical and historicized view of mathematical proof.

38. There is a large literature on this topic. See I. Grattan-Guinness, The Search for Mathematical Roots, 1870-1940: Logics, Set Theories and the Foundations of Mathematics from Cantor through Russell to Gödel (Princeton, N.J., 2000) for an overview. 
distinct ideas to the steps of the proof: discursive reason and intuition merged.

I call upon Hardy neither as an authority nor as an exemplum of some more pervasive trend in early twentieth-century mathematics. He was in fact rather quirky in his views on the philosophy of mathematics. He certainly was not unique in clinging to a form of mathematical understanding "guided, as in ordinary life, by 'intuition' and commonsense" ("MP," p. 17). Very few mathematicians, even those of the most formal and abstract persuasion, denied that some kind of intuition "remains the core of any mathematical achievement, even in the most abstract fields," as Richard Courant and Herbert Robbins asserted in their classic textbook What Is Mathematics? (1941). Admittedly, this book explicitly rejected the Hilbertian image of mathematics as "a game with definitions, rules, and syllogisms, without motive and goal." ${ }^{39}$ But even that citadel of mathematical abstraction and solidity, the Bourbaki group's famous series on Éléments de mathématiques, made concessions to intuition. After announcing their intention to "provide solid foundations of the all the rest of the treatise and indeed of the whole of modern mathematics" by adopting an uncompromisingly abstract and axiomatic approach, the Bourbaki hastened to add that examples had been strewn throughout the text to aid the reader whose patience might be sorely tried by having to "suspend his judgment until he has had the occasion to convince himself" of the material..$^{40}$

Hardy is of interest for my purposes because he acknowledged the Fregean strictures that sunder mathematical rigor from anything that smacked of the psychological (those dismissive remarks about rhetorical "gas") and yet at the same time defended a sense of rigor that still relied on meaning and vision of the inner eye (each step of the proof "scrutinised with the utmost care"). Rigor now resided in the step-by-step perusal of the proof, the discursive reason that had traditionally been the lot of humans, rather than in the flash of intuitive certainty apportioned to angels. The algorithms of arithmetic, transparent and sure-footed, became the ideal of such watertight, step-by-step proofs in the nineteenth-century movement to secure the foundations of analysis, particularly in the work

39. Richard Courant [and Herbert Robbins], "What Is Mathematics?" What Is Mathematics? An Elementary Approach to Ideas and Methods (New York, 1941), pp. xvii.

40. Nicolas Bourbaki, Théorie des ensembles, in Les structures fondamentales de l'analyse, in Éléments de mathématiques (Paris, 1939), 1.1.v, vi. Nicolas Bourbaki was the pseudonym of a collective of mathematicians who aimed to provide an entirely axiomatic exposition of modern mathematics; see Leo Corry, "Writing the Ultimate Mathematical Textbook: Nicolas Bourbaki's Éléments de mathématiques," in The Oxford Handbook of the History of Mathematics, ed. Eleanor Robson and Jacqueline Stedall (New York, 2009), pp. 565-88, which also describes the backlash against the Bourbaki approach. 
of Richard Dedekind, Weierstrass, and others. Starting with Gottlob Frege, the foundations of arithmetic were in turn subjected to critique and attempts made to ground them in logic. When mid-twentieth-century mathematicians protested in the name of intuition (an informal notion, which often had little or nothing to do with the mathematical school of intuitionism) against the increasing abstraction and pedantry of modern approaches epitomized by logical formalism on the one hand and Bourbaki structuralism on the other, they were not campaigning for a return to Cartesian epiphanies of self-evidence or even the masterful surveys of the coup d'oeil. Rather, they transferred the locus of intuition from sudden illumination to scrutiny of the entire proof. In yet another impossible hybrid, they crossed Cartesian self-evidence with Leibnizian proceduralism.

It is important to note that these defenses of step-by-step intuition antedate the digital computer. Any approach to proof that enshrined logical rigor had the unintended consequence of lengthening the demonstration. If every step, no matter how apparently trivial, must be made explicit, the number of steps inevitably balloons. The price of algorithmic transparency was a mind-numbing dilation of even the simplest mathematical operations. Russell and Alfred North Whitehead had intended their threevolume Principia Mathematica (1910-1913) to be just that: the foundations of mathematics laid down on unassailable logical principles. It became a standing joke that the proofs (all couched in a thicket of symbolism largely invented by Whitehead and Russell themselves) were so exhaustive and exhausting that it took until page 362 of the first volume to get to the proof of the proposition that " $1+1=2$," and then only as a promissory note, "when arithmetical addition has been defined" (fig. 8). ${ }^{41}$ The Bourbaki were sufficiently self-conscious about appearing pedantic that they relaxed their promise to employ "a rigorously correct language always" and countenanced occasional "abuses of language" without which "every mathematical text risks becoming pedantic or even unreadable." ${ }^{22}$ These minimal concessions to custom and brevity did not satisfy critics in the ranks, who continued to complain about the impenetrable abstraction of modern mathematics. ${ }^{43}$ What critics missed were motivating intuitions and "responsibility to the organic whole [of the proof], only guided by intrinsic necessity." ${ }^{44}$ Decades before computer-assisted proofs turned demonstrations

41. Alfred North Whitehead and Bertrand Russell, Principia Mathematica, 3 vols. (1910;

New York, 1925-1927), 1:362.

42. Bourbaki, Théorie des ensembles, p. vii.

43. See Alma Steingart, "Formalizing Abstraction in Cold War Mathematics," lecture, History of Science Society, San Francisco, 20 Nov. 2015.

44. Courant [and Robbins], "What Is Mathematics?," p. xvii. 


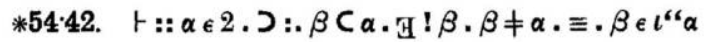

Dem.

ト.*54:4. つト:: $\alpha=\iota^{6} x \cup \iota^{6} y . \supset:$.

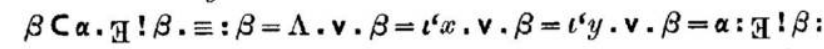

$[* 24 \cdot 53 \cdot 56 \cdot * 51 \cdot 161] \quad \equiv: \beta=\iota^{\natural} x \cdot \mathrm{v} \cdot \beta=\iota^{`} y \cdot \mathrm{v} \cdot \beta=\alpha$

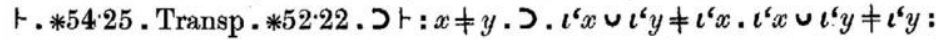

[*13.12] วト: $\alpha=\iota^{6} x \cup \iota^{6} y \cdot x \neq y . \supset . \alpha \neq \iota^{6} x \cdot \alpha \neq \iota^{6} y$

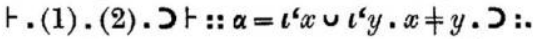

[*ŏ1·235]

$\beta \subset \alpha \cdot \operatorname{H} ! \beta \cdot \beta \neq \alpha \cdot \equiv: \beta=\iota^{\prime} x \cdot v \cdot \beta=\iota^{6} y:$

$[* 37 \cdot 6]$

$\equiv:($ 壮 $z) \cdot z \in \alpha \cdot \beta=\iota^{\prime} z$ :

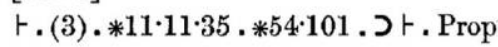

$\equiv: \beta \in \iota^{\prime \prime} \alpha$

$* 54.43$. $\vdash: . \alpha, \beta \in 1 . \supset: \alpha \cap \beta=\Lambda . \equiv . \alpha \cup \beta \in 2$

Dem.

ト.*54:26.วト: . $\alpha=\iota^{6} x \cdot \beta=\iota^{6} y . \supset: \alpha \cup \beta \in 2 . \equiv . x \neq y$.

[*51·231]

[*13:12]

$\equiv \cdot \iota^{6} x \cap t^{6} y=\Lambda$.

ト.(1).*11.11.35.J

$\equiv . \alpha \cap \beta=\Lambda$

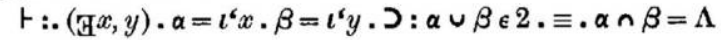

ト. (2) $\cdot * 11 \cdot 54 \cdot * 52 \cdot 1$. วト.Prop

From this proposition it will follow, when arithmetical addition has been defined, that $1+1=2$.

*54.44. $\vdash:: z, w \in \iota^{6} x \cup \iota^{\varsigma} y \cdot \supset_{z, w} \cdot \phi(z, w): \equiv \cdot \phi(x, x) \cdot \phi(x, y) \cdot \phi(y, x) \cdot \phi(y, y)$

Dem.

ト .**51·234.**11·62.つト : $z, w \in \iota^{6} x \cup \iota^{6} y . \supset_{z, w} \cdot \phi(z, w): \equiv:$ $z \in \boldsymbol{l}^{\boldsymbol{b}} x \cup \boldsymbol{l}^{\boldsymbol{b}} y \cdot \mathrm{J}_{z}, \phi(z, x) \cdot \phi(z, y):$

$[* 51 \cdot 234 \cdot * 10 \cdot 29] \equiv: \phi(x, x) \cdot \phi(x, y) \cdot \phi(y, x) \cdot \phi(y, y): . \supset$ ト. Prop

*54.441. ト :: $z, w \in \iota^{6} x \cup \iota^{6} y \cdot z \neq w . \supset_{z, w} . \phi(z, w): \Xi: . x=y: \mathbf{v}: \phi(x, y) . \phi(y, x)$

Dem.

ト.**5. 6. つト:: $z, w \in \iota^{6} x \cup \iota^{6} y . z \neq w . \supset_{z, w} . \phi(z, w): \equiv:$. $z, w \in \iota^{\mathfrak{s}} x \cup \iota^{\mathfrak{s}} y \cdot \boldsymbol{\supset}_{z, w}: z=w \cdot \mathbf{v} \cdot \phi(z, w):$.

[*54:44] $\quad \equiv: x=x \cdot \mathrm{v} \cdot \phi(x, x): x=y \cdot \mathrm{v} \cdot \phi(x, y):$ $y=x \cdot \mathbf{v} \cdot \phi(y, x): y=y \cdot \mathbf{v} \cdot \phi(y, y):$

[*13:15] $\equiv: x=y \cdot \mathbf{v} \cdot \phi(x, y): y=x \cdot \mathbf{v} \cdot \phi(y, x):$

$[* 13 \cdot 16 \cdot * 4 \cdot 41] \equiv: x=y \cdot \mathbf{v} \cdot \phi(x, y) \cdot \phi(y, x)$

This proposition is used in $* 163 \cdot 42$, in the theory of relations of mutually exclusive relations.

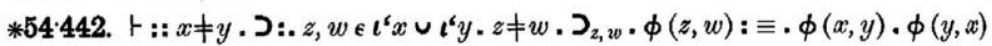

[*54.441]

FIGURE 8. "From this proposition it will follow, when arithmetical addition has been defined, that $1+1=2$ " (Whitehead and Russell, Principia Mathematica, 1:362). 
into thousands of lines of code in the 1970s, mathematicians were already fretting that the sheer length and abstraction of modern proofs had made them inscrutable to the understanding.

Or rather, to a certain kind of understanding. By shifting the locus of intuition from lightning flashes of self-evidence to the step-by-step argument, mathematicians like Hardy had relinquished neither the holism nor the structural interconnections nor the irrefragable and indubitable force of coup d'oeil understanding. Even if tracing the ridge of the mountains until one could make out the next peak was a process that unfolded in time, once discerned, the path connecting the peaks could be grasped as a whole and followed onward to still further discoveries. Just as in the case of the military coup d'oeil learned by literally surveying mountains, what began as a step-by-step exploration fused into a continuous line of argument, if not into Descartes's all-at-once insight. Proponents of formalist proofs could and did however counter with a rival form of understanding, one more rigorous, coherent, self-sufficient, precise, and general..$^{45}$ The Hungarian-born mathematician George Pólya, who wrote extensively on the role of heuristics in mathematics, attempted to bridge the rift by effectively distinguishing between a context of discovery and a context of justification in mathematics, although he did not use those terms. Whereas demonstrative reasoning must satisfy "rigid standards, codified and clarified by logic," plausible reasoning (induction, analogy, pattern finding) was "hazardous, controversial, and provisional" — but also essential to creativity. "You have to guess a mathematical theorem before you can prove it; you have to guess the idea of the proof before you carry through the details." 46

Many mathematicians nonetheless continued to insist that demonstrations, not just discoveries, must satisfy intuition, almost always described in visual metaphors, regardless of whether the subject matter was geometry or analysis. In an unpublished manuscript, Wittgenstein seems to have entertained similar views, to the point of denying the superiority of logical proofs that failed to provide such an understanding: "The proof must be intuitive [anschaulich sein]: if we are no longer convinced by what we see, then the proof has lost its force. No matter, whether it is construed ac-

45. See Herbert Mehrtens, Moderne, Sprache, Mathematik: Eine Geschichte des Streits um die Grundlagen der Disziplin und des Subjekts formaler Systeme (Frankfurt am Main, 1990); Corry, Modern Algebra and the Rise of Mathematical Structures (Boston, 2004); Curtis Franks, The Autonomy of Mathematical Knowledge: Hilbert's Program Revisited (New York, 2009).

46. George Pólya, Induction and Analogy in Mathematics, vol. 1 of Mathematics and Plausible Reasoning, 2 vols. (1954; Princeton, N.J., 1990), pp. v, vi. 
cording to the 'logical' schema of Russell or otherwise." 47 Did a proof that failed to demonstrate, in the root sense of showing (monstrare), fail to prove, in spite of - or perhaps because of - its claims to technical rigor?

The advent of computer-assisted proofs, exemplified most spectacularly by the 1976 announcement of the proof of the four-color theorem by Kenneth Appel and Wolfgang Haken using twelve hundred hours of computing time on three computers plus months of human time proofreading the programs, undammed a torrent of similar complaints from mathematicians. Their hostility was not directed toward the result itself, accepted by most, but the means by which the result had been achieved. Could a proof that black-boxed key elements in computer calculations carry conviction? Some did throw up their hands at the sheer length of the proof, but the chief criticism was the inscrutability of the computer algorithms. ${ }^{48}$ Whereas formalist or abstract proofs had baffled understanding by their inflated length or missing motivation, the computer-assisted proofs eluded human grasp by their opacity. Computers and humans both calculate by step-by-step algorithms but not the same algorithms. Procedures that were transparent for humans were not necessarily efficient for computers. This much had been clear since the first phases of artificial intelligence in the 1950s, when Allen Newell and Herbert Simon's Logic Theorist program, which attempted to imitate the heuristics used by human mathematicians (partially inspired by Pólya's work), was bested by Hao Wang's IBM 704 program, which capitalized on nonhuman computers as "persistent plodders," in a competition as to which program could prove more theorems from the first volume of Principia Mathematica faster. ${ }^{49}$

Nor was this contrast between algorithms executed by humans and by machines specific to digital computers. Soon after mechanical calculators came into widespread use around 1900, the demands of efficiency imposed "marked divergences between the operational rules favorable to manual calculation and the rules favorable, on the contrary, to mechanical calculation." 50 Since at least the early nineteenth century, before any machine could reliably calculate, calculation had been denigrated as "mechanical,"

47. Quoted in Mühlhölzer, “'A Mathematical Prof Must Be Surveyable,”” p. 82.

48. Donald MacKenzie, Mechanizing Proof: Computing, Risk, and Trust (Cambridge, Mass., 2001), pp. 101-49, explains both the proof strategy and canvases the diverse reactions of mathematicians.

49. Quoted in Mackenzie, Mechanizing Proof, p. 71. See also Stephanie Dick, "Of Models and Machines: Implementing Bounded Rationality," Isis 106 (Sept. 2015): 623-34.

50. Louis Couffignal, Les Machines à calculer: Leurs principes, leur évolution (Paris, 1933), p. 41. On the long history of unsuccessful attempts to build reliable calculating machines, see Matthew L. Jones, Reckoning with Matter: Calculating Machines, Innovation, and Thinking about Thinking from Pascal to Babbage (Chicago, 2016). 
because the algorithms involved were too simple, too transparent to merit serious mathematical attention. ${ }^{51}$ The work of heavy-duty calculation in astronomical observatories and nautical almanacs was accordingly assigned to low-paid, relatively unskilled labor: schoolboys and later women..$^{52}$ But once real machines, whether analog or digital, began to calculate according to algorithms tailored to their capacities, even the most basic algorithms of arithmetic turned opaque.

\section{Darkling Intuition}

Although formalist, abstract, and computer-assisted proofs differed as to their goals (rigor, generality, and efficiency, respectively) and detailed execution, they provoked similar complaints on the part of the mathematicians who longed for demonstrations that they could see. Why? After all, the ludicrous length of formalist proofs à la "Russell" shared little with the ethereal abstraction of structuralist proofs à la Bourbaki, and neither deployed the opaque algorithms used by mechanical calculators or digital computers. The only common denominator was that all somehow undermined intuition and understanding.

But what was intuition? Certainly not the immediate grasp of intelligible forms of thirteenth-century angelology, nor Descartes's mathematical demonstration sped up into a burst of self-evidence, nor even the at-a-glance mountaintop survey of the military coup d'oeil: centuries of philosophical rumination-Immanuel Kant's Anschauung, Henri Bergson's méthode intuitive, G. E. Moore's moral intuitionism-had barnacled the term with quite different and diverse associations. Moreover, in mathematics the quest for rigorous foundations in the nineteenth and twentieth centuries had pried rigor and intuition apart. The problem of appealing to intuition (Anschauung) in proofs, claimed Frege, was that one "proceeded by leaps" without even detecting the gaps in the argument. Worse, the "purely intuitive cannot be communicated." ${ }^{3}$ Intuition became the subject matter of psychology, and the psychology of the unconscious at that: a dar-

51. See for example Charles Babbage's description of the calculations performed by hand in the logarithm project organized by Gaspard de Prony as "mechanical" (Charles Babbage, On the Economy of Machinery and Manufactures [London, 1835], pp. 195, 201). On the Prony project, see Daston, “Enlightenment Calculations," Critical Inquiry 21 (Autumn 1994): 182202.

52. See Mary Croarken, "Human Computers in Eighteenth- and Nineteenth-Century Britain," in The Oxford Handbook of the History of Mathematics, pp. 375-403, and David Alan Grier, When Computers Were Human (Princeton, N.J., 2006).

53. Gottlob Frege, Die Grundlagen der Arithmetik: Eine logisch-mathematische Untersuchung über den Begriff der Zahl (1884; Breslau, 1934), pp. 35, 102. 
kling faculty, a gut feeling inaccessible to analysis and too perilously close to mysticism to be intellectually respectable.

Yet the form of understanding that invokes intuition, especially but not exclusively in mathematics, has stubbornly persisted. In this context, intuition discovers, explains, and proves. It is intuition that grasps the proof as a whole, reveals interconnections, and creates conviction that a proof really does prove. Despite all the doubts that have shadowed intuition in mathematics since the latter half of the nineteenth century, its damaging associations with deepest, darkest subjectivity, and the near impossibility of defining it clearly, the distinctive form of understanding that crystallized around this vague and protean notion endures. Still more remarkable, this form of understanding has in the main retained its contours over centuries, despite contrasting domains of application, from angelic cognition to military reconnaissance to mathematical demonstration. Ideally, it seizes upon essentials, forges a whole out of disparate parts or steps, is literally or figuratively a way of seeing, brooks no doubt, resists conscious analysis - and hits with the suddenness of a thunderbolt. Most remarkable of all, in every articulation, it harbors some impossibility at its core: form apprehended without matter; discursive and intuitive reason fused, overview and details grasped simultaneously, self-evidence and step-by-step procedure convergent. Despite frequent appeals to common sense by its champions among mathematicians and philosophers, there is nothing common about coup d'oeil understanding-except perhaps the yearning to see like an angel. 